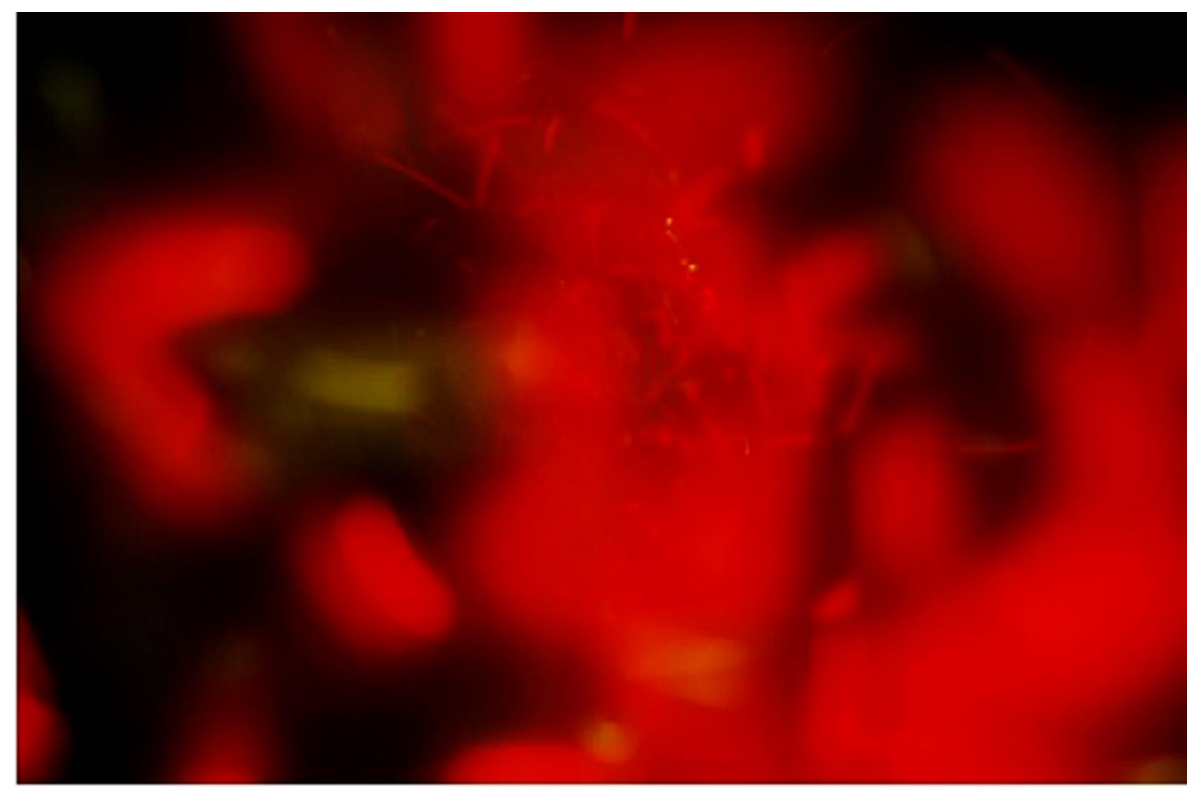

Rubens Rangel

\title{
A arte cinematográfica como possibilidade de permanência da fantasia e da imaginação
}

\section{Dilma Beatriz Rocha Juliano}

Mestre em Literatura Brasileira e Doutora em Teoria Literária/UFSC. Professora dos Cursos de letras e de Comunicação Social - habilitações em Jornalismo, Publicidade e Cinema-Audiovisual da Universidade do sul de Santa Catarina/UNISUL. Pesquisadora na linha de narrativas em audiovisuais.

EM BUSCA DA TERRA DO NUNCA. Direção: Marc Forster. Intérpretes: Johnny Deep; Dustin Hoffman; Julie Christie; Katie Winslet. Fotografia: Roberto Schaefer. Reino Unido, Estados Unidos: Lumière, Miramax Films, 2004. 1 DVD (106 min.), color.

A indicação feita pela Lei de Diretrizes e Bases da Educação Nacional de que a escola deva preparar-se para ensinar Mc Luhan tanto quanto Gutemberg é indicadora da necessidade da leitura de imagens. Não se trata de educar adultos e crianças para a leitura das narrativas imagéticas, numa retomada 
iluminista da "educação do gosto", mas de indicar o exercício do ver como forma de demonstrar a polissemia das imagens.

- filme Em busca da terra do nunca é um belo exemplo das inúmeras possibilidades de sentido que se pode encontrar na produção cinematográfica. Essa película situa-se numa interessante fronteira - tanto pode ser consumida por adultos como uma história de amor impossível, ao contrapor vida e morte, quanto pode ser lida por crianças como um conto de fadas, nos moldes da "cultura da criança" enunciada por Walter Benjamin(1), como "o mundo autêntico daqueles contos [de fadas], [que] não é idílico, é belo e cruel".

Um filme dentro de um filme, assim parece desdobrar-se a narrativa de Em busca da terra do nunca. Na superfície das imagens é possível ver a estética hollywoodiana mais conhecida como imagem mercadoria: a imagem que se vende fácil pela repetição indiscutível do entretenimento. No entanto, nas dobras do filme, o processo criativo da peça Peter Pan confunde-se com a própria história de convencimento sobre a criatividade e a imaginação como componentes inseparáveis da vida humana. Duas histórias que se dobram e desdobram nesse filme - uma mostrando os adultos que, mesmo infelizes e conformados aos padrões sociais, buscam desempenhar a função de educar as crianças na lógica burguesa, aquela do

concidadão útil, socialmente confiável e ciente de sua posição. [...] "As crianças têm mais necessidade de nós do que nós delas", esta é a máxima não confessada dessa classe [burguesa], que subjaz tanto às especulações mais sutis de sua pedagogia como à sua prática da reprodução(2) .

A outra história mostra que na terra imaginária tudo está por ser inventado. Peter, a criança que no filme é mais resistente à fantasia, aprende no decorrer da história que a imaginação não é o inverso da maturidade. Talvez o que melhor se possa ler no texto-imagem é que imaginação e fantasia são ingredientes fundamentais para a consciência do adulto maduro. Buscar as respostas para os problemas da vida na materialidade das trocas, usando as regras da realidade já conhecida, pode gerar angústia, redobrar o sofrimento e sobrepesar os problemas. Ao contrário disso, recorrer à imaginação, buscar na terra do nunca o refúgio ao trágico da existência pode, surpreendentemente, fazer-nos esbarrar em jogos até então impensados. Imaginar é inventar outras lógicas, é criar sentidos ainda não experimentados.

É certo que o filme, em certos momentos, esbarra em maniqueísmos morais, mas eles não chegam a comprometer as possibilidades de leitura com um conteúdo ideológico de imagens plasmadas na estética mercadológica. 
Sem dúvida, o ponto alto da estética do filme é a encenação da história de Peter Pan. É ali que se revela toda a potência imaginativa da criança. Benjamin(3) afirma que "a encenação contrapõe-se ao treinamento pedagógico como libertação radical do jogo, processo que o adulto pode tão-somente observar". Marc Forster nos faz observar "as energias das crianças" em contraposição aos "embaraços da pedagogia burguesa"; embaraços ali representados pela dureza dos adultos, em trajes blacktie e atitude circunspeta, que se instalam no teatro em busca de uma terra sempre reconhecida.

A imaginação e a capacidade de improvisação se confundem na criatividade infantil em cena. É também na encenação da peçaPeter Pan que se dá o ápice da narrativa fílmica. Naquele momento, as crianças - tanto as que estão na platéia quanto as que estão no palco - mostram aos adultos o valor da fantasia: é ali que a arte revela a necessidade de que se acredite nela e que se extrapole com ela os limites da vida regrada. Não se trata, portanto, de um chamamento à sensibilidade? Nesse caso, não somos provocados a desconstruir nossa percepção do mundo e irmos em busca da terra do nunca?

o conjunto de elementos, a música, os enquadramentos de câmera, as imagens em movimento, os atores, o figurino, os cenários, a linguagem dos personagens compõem uma estética que pode despertar a sensibilidade anestesiada pelo cotidiano da vida, proporcionando aquilo que se chama de experiência estética - "novas forças, novas inervações vêm à luz, das quais o diretor jamais teve qualquer vislumbre durante 0 trabalho (4)."

\section{Notas}

[1] $1984 . p \cdot 15$.

[2] $1984 \cdot \mathrm{p} \cdot 87$.

[3] BENJAMIN, $1984, \mathrm{p} .89$.

[4] BENJAMIN, 1984, p. 88.

\section{Bibliografia}

BENJAMIN, Walter. Reflexões: a criança, o brinquedo, a educação. Tradução de Marcos Vinícius Mazzari. São Paulo: Summus, 1984. 